\title{
THE EFFECTIVENESS OF COOPERATION OF INDUSTRIAL ENTERPRISES
}

\author{
Romualdas Ginevičius \\ Vilnius Gediminas Technical University, Saulètekio al. 11, LT-12230 Vilnius, Lithuania \\ E-mail: romualdas.ginevicius@vgtu.lt
}

Received 15 January 2010; accepted 15 April 2010

\begin{abstract}
Cooperation is a strategy of an enterprise, seeking to retain its market share. The cooperation means the establishment of long-term relations of production between economically and legally independent enterprises. The measurement of the level of cooperation achieved plays an important part in this process because it helps to determine the effect of cooperation on the efficiency of commercial activities of an enterprise, as well as the extent of cooperation influence, the conditions required for effective cooperation of enterprises, etc. In the present investigation, the analysis of the cooperation influence on the competitiveness of an enterprise is made, based on the suggested formula for determining the level of the cooperation achieved by enterprises. The analysis performed shows that this influence is not strong, implying that the appropriate organisational forms of cooperation have not been found yet. Cooperation mainly affects the profitability of an enterprise. The analysis of cooperation in the area of production shows that cooperation in production, and the development of new technologies and new products is most important for achieving enterprise profitability. The number of partners also has a great influence on cooperation effectiveness.
\end{abstract}

Keywords: cooperation of enterprises, cooperation measurement, cooperation influence on commercial activities of an enterprise.

Reference to this paper should be made as follows: Ginevičius, R. 2010. The effectiveness of cooperation of industrial enterprises, Journal of Business Economics and Management 11(2): 283-296.

\section{Introduction}

The main condition of enterprise survival under market economy is its competitiveness. The actions aimed at decreasing the number of the existing and potential competitors are referred to as strategic management. The above actions are much more complicated than proper determining of costs and volumes of production. Strategic management embraces a number of actions taken by an enterprise seeking to achieve higher profit by affecting the market. On the other hand, an enterprise should adapt itself to the continually changing environment to remain on the market (Auškalnyte and Ginevičius 2001; Ginevičius 1998). There are two main methods of strategic management - concentration of production and cooperation. The strategic management of cooperation includes joint 
actions of competing enterprises for the benefit of each of the partners (Barzdenyte 2000; Novickas and Savanevičiene 2000). Under the conditions of global economics these actions help to create new possibilities and search for new sources of profit, based on the available resources. Cooperation can promote the development of new products and their introduction to the market, as well as new market research with the aims of entering it, etc. (Blohm 1980; Savanevičienè 2001).

The enterprises not capable to produce and sell the desired products because of the lack of finances and labour force usually cooperate with other enterprises. Thus, cooperation means working together of two or more independent enterprises for a long time in any area of activities with the aim of obtaining a synergetic economic effect by the partners (Sakalas and Savanavičienè 2000).

Cooperation of small- and medium-size enterprises helps them to smooth the negative effects of insufficient experience, not properly developed marketing, lack of state support, etc. (Brandenburger 1997; Kaul 1999). It can also help such enterprises to strengthen their position in the market or even to survive by cooperating with a large enterprise (Kaul 1999; Beamish 1988).

When a group of small- and medium-size enterprises located in the same area start to cooperate, regional networks are formed. Their functions are diverse and flexible, embracing the analysis of the state of the market, price regulation, the control of raw materials, etc. The above enterprises can also make trade associations (of a branch of industry).

Cooperation is often confused with concentration. The essential difference between the strategic management of these activities of two enterprises is shown in Fig. 1 (Ginevičius and Andruškevičius 2000; Ginevičius 2000).

Thus, the cooperation of enterprises reflects the cases, when they make an agreement about joint activities but remain legally and economically independent. In all other cases, when enterprises have no legal or economic independence or both, we have actually a new enterprise, reflecting the concentration of production.

\begin{tabular}{|c|c|c|c|}
\hline & & \multicolumn{2}{|c|}{ Legal status of an enterprise } \\
\hline & & Independent & Dependent \\
\hline \multirow{2}{*}{ 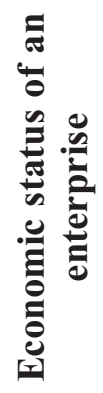 } & $\begin{array}{l}\overrightarrow{0} \\
\overrightarrow{0} \\
\bar{d} \\
\overrightarrow{0} \\
. \Xi \\
. \Xi\end{array}$ & Cooperation & Concentration \\
\hline & $\begin{array}{l}\overrightarrow{0} \\
\overrightarrow{0} \\
\overrightarrow{0} \\
\overrightarrow{0}\end{array}$ & Concentration & Concentration \\
\hline
\end{tabular}

Fig. 1. Differences between concentration and cooperation 
Therefore, cooperation may be defined as the establishment of long-term relations in production between legally and economically independent enterprises (Benisch 1991; Bleicher 1992).

In the literature, various approaches to the analysis of concentration (and its measurement) (Ginevičius 1998, 2005, 2009; Ginevičius and Čirba 2007, 2009) can be found. However, this does not apply to cooperation (Albino et al. 2007; Brenner 2005; Lawson et al. 2008; Royer and Simons 2009; Shan et al. 1994; Stark et al. 2008). It is evident that without quantitative evaluation of cooperation development it is hardly possible to assess its effect on enterprise commercial activities, as well as the extent and limits of this effect, the conditions ensuring economic effectiveness of cooperation, etc.

\section{The conditions required for cooperation development}

The analysis of the literature on the problem shows that there are quite a few approaches to the conditions required for cooperation of enterprises. However, it is often emphasized that, in any case, the required conditions include friendly relations between the potential partners, mutual trust and loyalty, as well as meeting the commitments by the partners. These four conditions make the basis for long-term cooperation (Fig. 2). This approach to cooperation is supported by the followers of the social exchange theory (Blau 1964; Sutcliffe and Zaheer 1998; Granovetter 1985; Uzzi 1997).

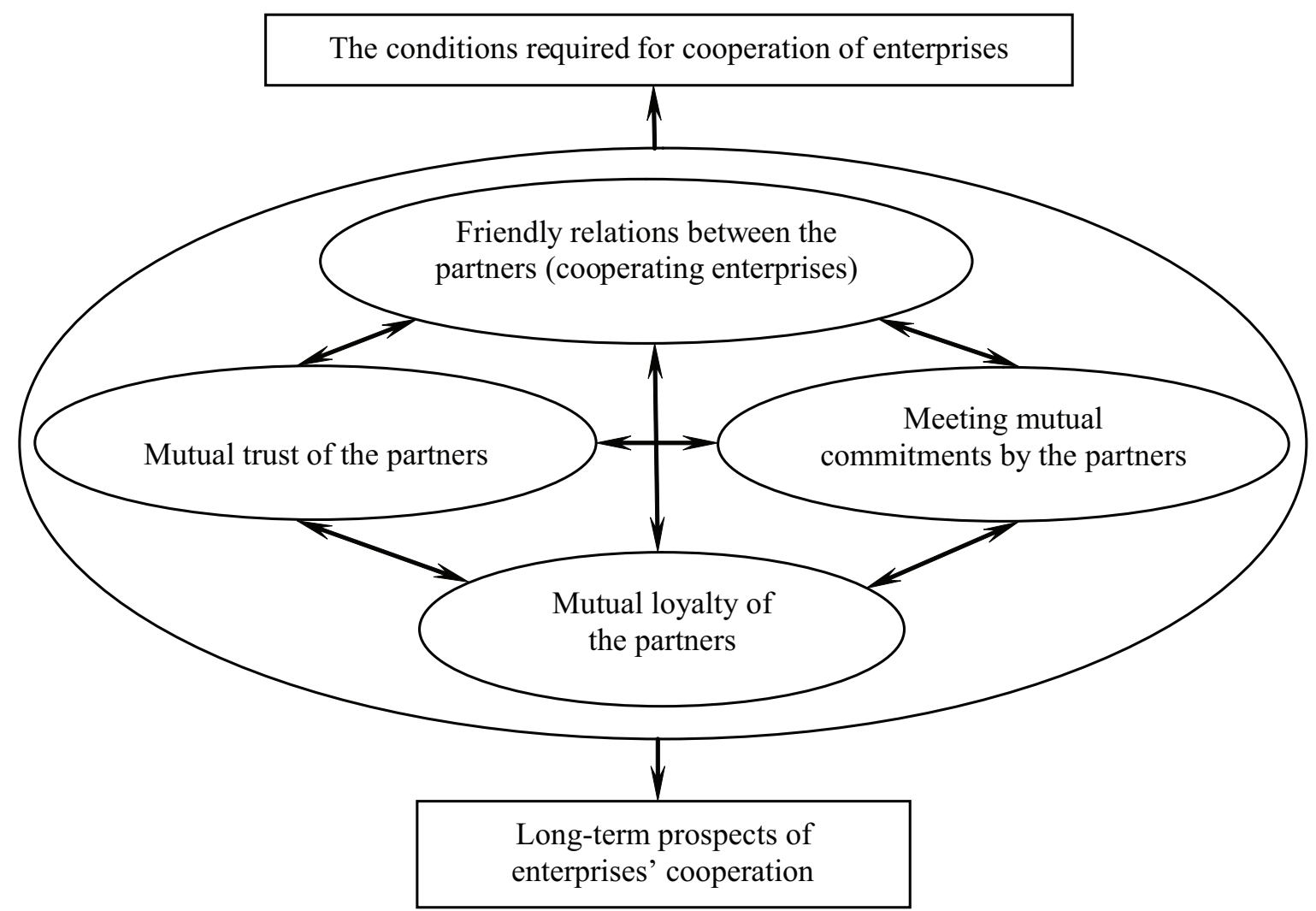

Fig. 2. A model reflecting the approach to cooperation by the followers of social exchange theory 
In the case presented in Figure 2, the axis of successful cooperation is the cooperation based on long-term joint actions (Wetzels 1998; Gulati and Gargiulo 1999), and the belief in its success (Axelrod 1984).

Personal relations based on friendship are the result of common work and leisure time spent together by individuals and organisations. Friendly relations can promote cooperation, increasing the loyalty, mutual trust and meeting the commitments by the partners (Sutcliffe and Zaheer 1998). Therefore, the relationships between the partners are actually of the same importance as the products sold or services provided by them. As shown in Figure 2, friendly relations are based on partners' loyalty, and meeting the commitments to each other.

Loyalty strengthens the relationships, increasing mutual trust and meeting the commitments by the partners (Uzzi 1997). Companies are seeking loyalty not only from their employees. They develop strategies aimed at increasing the number of loyal partners. The experience of successfully operating enterprises shows that even the change of clients or employees can have no grave consequences if made gradually. However, quick changes can increase risks and losses. Gaining mutual loyalty of the partners is a complicated process. It can be successful, if the partners enjoy friendly relations and environment (Gounaris 2005). As shown in Figure 2, the main conditions of achieving loyalty are friendly relations, trust of the partners and meeting mutual commitments.

Trust of the partners is required because cooperation is a complicated process. It is based on honesty, openness and responsibility (Morgan and Hunt 1999) and is often associated with experience. Trust can be gained in the long time, and if broken, the relationships should be built up all over again. As shown in Figure 2, the main conditions of gaining trust are friendship, loyalty and meeting the commitments.

The commitments are the criterion showing the loyalty of a person to his/her company or the loyalty of partners to each other (Gundlach 1995).

Meeting the commitments means that partners are going to continue cooperation. The commitments show that partners want to exchange information in the future and make joint decisions. Successful long-term relationships are possible when the commitments of the partners to each other are strong. The experience shows that the cases of not meeting mutual commitments by the partners often cause the failure of cooperation. As shown in Figure 2, the main conditions ensuring meeting the commitments are friendly relations between the partners, mutual loyalty and trust.

Therefore, the followers of the social exchange theory believe that, on the one hand, personal relations, such as friendship, loyalty, trust and meeting the commitments, are factors ensuring successful cooperation of the partners, on the other hand, successful cooperation strengthens personal relations.

Other researchers think that the main factors determining successful cooperation include the proper choice of cooperation aims, effective decision making, organisation of activities and management, as well as the experience in operating in the market (Levinthal and March 1993; Edquist 1997; Rumelt 1991). There are also the supporters of cooperation who associate the results of cooperation with successful application of the theory 
of mediation (Zajac 1990), the economy of costs by business-to-business transactions (Williamson 1981), differentiation of resources (Teece et al. 1997), partners' diversification (Porter 1980), etc. They believe that the above factors largely determine the effectiveness of the performance of cooperating enterprises.

\section{Measuring the cooperation of enterprises}

In the literature on the problem of cooperation of enterprises, the emphasis is placed on theoretical study of its conditions, advantages and disadvantages, the influence on enterprise performance, etc. However, any process may be affected or controlled when it can be measured. It has been already described how cooperation shows itself and what particular forms it takes. The analysis of the forms of enterprises' cooperation revealed the conditions determining the level of cooperation. Not all of them are relevant. Their analysis has shown that the following three criteria should be considered:

1. The number of partners (cooperating enterprises).

2. The number of joint production functions.

3. The rate of functional cooperation.

To determine the level of enterprise cooperation, the above criteria should be integrated into a single generalizing criterion. However, the influence of each criterion of enterprises' cooperation on the generalizing criterion should be determined first, depending on the type of its variation. It is hardly possible to state firmly that the increasing number of partners increases the effectiveness of their cooperation.

It is clear that it increases with the growth of the number of partners because the potential of interfirm networks increases. They get a possibility to compete with larger market players, dictating their conditions to them, while their benefits are growing due to synergetic effect, etc. However, this situation remains until some limits are reached. Then, the network becomes too large, stiff, difficult to control and slowly responding to the changing conditions, etc. The influence of the number of partners on cooperation effectiveness is shown in Figure 3.

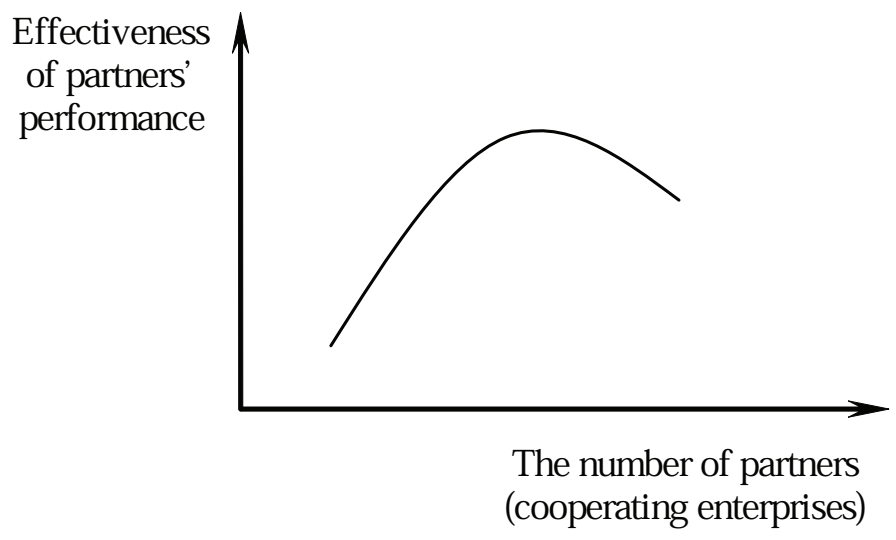

Fig. 3. The dependence of enterprises' cooperation effectiveness on the number of partners 
It is believed that similar dependence may be found between the influence of the number of joint production functions and the rate of functional cooperation on cooperation effectiveness. In this case, the effectiveness of cooperation is growing until a certain level, but when these functions or the rate of their joining up exceed a certain number, cooperation effectiveness begins to decrease (for similar reasons as in the previous case).

To answer the question about the influence of all three criteria of enterprise cooperation (i.e. the number of partners, joint functions and the rate of functional cooperation), the relationships of each criterion should be determined by using the following models:

$$
\begin{aligned}
& E=f\left(P_{i j}\right), \\
& E=f\left(W_{i j}\right), \\
& E=f\left(S_{j}\right),
\end{aligned}
$$

where $E$ denotes the results of commercial enterprise activities, described by particular criteria (financial, profitability, etc.); $P_{j}$ is the number of partners of the $j$-th function's of the $i$-th cooperation form; $W_{j}$ is the rate of joining up the $j$-th function of the $i$-th cooperation form with other functions; $S_{j}$ is the $j$-th enterprise function.

The determination of the extremum of each of the above three cooperation criteria based on the models (1-3) (Fig. 1) and their integration into a single cooperation level formula would allow us to determine optimal cooperation level.

As mentioned above, to determine the actual enterprise cooperation level, all three criteria describing it should be integrated into one magnitude. This may be performed as follows:

$$
K=\frac{\sum_{j=1}^{N} S_{j}\left(\sum_{i=1}^{m} P_{i j} W_{i j}\right)}{\sum_{j=1}^{N} S_{j}},
$$

where $K$ is the cooperation level of the considered enterprise.

The value $K$ is actually a suggested cooperation measure. To determine its suitability for practical calculations, the calculations based on the results of actual enterprises' performance should be made.

\section{Calculations of the cooperation level of enterprises}

The calculations were made based on the analysis of industrial enterprises, operating in 12 various areas ${ }^{1}$. Experts answered the questions about the production functions of

\footnotetext{
${ }^{1}$ The data on the cooperation level of the considered enterprises were obtained from the work of the MSc student of the Business Management Faculty Virgilijus Noreika, who made the required calculations.
} 
these enterprises and which of them were jointly performed. They also determined the rate of functional cooperation at the enterprises considered. The results of the survey are presented in Tables 1 and 2.

Table 1. General production functions of enterprises

\begin{tabular}{c|l}
\hline No. & Function \\
\hline & Supply \\
2 & Production \\
3 & Development of new technologies and \\
4 & products \\
5 & Transportation \\
6 & Selling of products \\
& Services \\
\hline
\end{tabular}

Table 2. The rate of functional enterprise production cooperation

\begin{tabular}{|c|c|c|}
\hline No. & $\begin{array}{l}\text { A description of functional } \\
\text { cooperation }\end{array}$ & $\begin{array}{l}\text { Cooperation } \\
\text { rate } \\
\text { coefficient }\end{array}$ \\
\hline 1 & $\begin{array}{l}\text { All products are produced and } \\
\text { sold and services are provided } \\
\text { by an enterprise }\end{array}$ & 0 \\
\hline 2 & $\begin{array}{l}\text { Production and selling } \\
\text { operations are coordinated }\end{array}$ & 0.17 \\
\hline 3 & $\begin{array}{l}\text { Some of the functions are } \\
\text { transferred to partners, while } \\
\text { others are performed by an } \\
\text { enterprise itself }\end{array}$ & 0.33 \\
\hline 4 & $\begin{array}{l}\text { Semi-finished items required } \\
\text { for production are obtained } \\
\text { from partners or are sent to } \\
\text { them. }\end{array}$ & 0.50 \\
\hline 5 & $\begin{array}{l}\text { Agreements are made with } \\
\text { other enterprises about getting } \\
\text { the products or services }\end{array}$ & 0.67 \\
\hline 6 & $\begin{array}{l}\text { Some functions are performed } \\
\text { by a jointly established } \\
\text { department }\end{array}$ & 0.84 \\
\hline 7 & $\begin{array}{l}\text { All functions are performed } \\
\text { by a jointly established } \\
\text { department }\end{array}$ & 1.00 \\
\hline
\end{tabular}


Based on the available data about the investigated enterprises, the following coefficients were calculated for them:

$\mathrm{K}$ (total cooperation coefficient);

$\mathrm{K}_{1}$ (cooperation coefficient for the supply function);

$\mathrm{K}_{2}$ (cooperation coefficient for the production function);

$\mathrm{K}_{3}$ (cooperation coefficient for the function of development of new technologies and products);

$\mathrm{K}_{4}$ (cooperation coefficient for transportation function );

$\mathrm{K}_{5}$ (cooperation coefficient for the function of selling the products);

$\mathrm{K}_{6}$ (cooperation coefficient for the function of the provision of services).

The results obtained in calculating the above coefficients using formula (4) are given in Table 3. The data from Table 3 are also presented in the graphical form in Figure 3 for visual effect.

As shown in Table 3 and Figure 4, the highest cooperation level was determined for supply and production functions; average cooperation level was stated for transportation, selling of the manufactured products and provision of services; the lowest cooperation level was found for the function of developing new technologies and products.

Table 3. The results obtained in calculating the total cooperation coefficient and cooperation coefficients of production functions of enterprises

\begin{tabular}{|c|c|c|c|c|c|c|c|}
\hline \multirow[b]{2}{*}{ 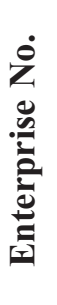 } & \multicolumn{6}{|c|}{ The values of cooperation coefficients of production functions } & \multirow[b]{2}{*}{$\begin{array}{c}\text { Total } \\
\text { cooperation } \\
\text { coefficient } \\
(\mathrm{K})\end{array}$} \\
\hline & $\begin{array}{l}\text { supply } \\
\left(\mathrm{K}_{1}\right)\end{array}$ & $\begin{array}{l}\text { production } \\
\qquad\left(\mathrm{K}_{2}\right)\end{array}$ & $\begin{array}{c}\text { development } \\
\text { of new } \\
\text { technologies } \\
\text { and } \\
\text { products }\left(\mathrm{K}_{3}\right)\end{array}$ & $\begin{array}{c}\text { transportation } \\
\qquad\left(\mathrm{K}_{4}\right)\end{array}$ & $\begin{array}{l}\text { selling } \\
\text { of } \\
\text { products } \\
\left(\mathrm{K}_{5}\right)\end{array}$ & $\begin{array}{l}\text { provision } \\
\text { of } \\
\text { services } \\
\left(\mathrm{K}_{6}\right)\end{array}$ & \\
\hline 1 & 2 & 3 & 4 & 5 & 6 & 7 & 8 \\
\hline 1 & 0.170 & 7.920 & 0.170 & 4.080 & 4.680 & 2.310 & 19.330 \\
\hline 2 & 1.925 & 8.633 & 0.825 & 1.950 & 0.000 & 3.350 & 16.683 \\
\hline 3 & 2.50 & 10.000 & 1.490 & 1.000 & 3.020 & 1.680 & 19.690 \\
\hline 4 & 0.88 & 7.800 & 0.000 & 4.467 & 0.000 & 6.213 & 19.360 \\
\hline 5 & 2.87 & 1.100 & 0.000 & 1.580 & 2.107 & 0.000 & 7.033 \\
\hline 6 & 3.010 & 3.230 & 0.840 & 4.020 & 2.850 & 2.010 & 15.96 \\
\hline 7 & 2.125 & 1.375 & 0.000 & 1.375 & 1.558 & 1.558 & 7.992 \\
\hline 8 & 5.150 & 1.100 & 0.275 & 0.000 & 2.217 & 0.425 & 9.167 \\
\hline 9 & 7.400 & 2.970 & 2.680 & 3.640 & 2.040 & 1.320 & 20.050 \\
\hline
\end{tabular}


Continued Table 3

\begin{tabular}{c|c|c|c|c|c|c|c}
\hline 1 & 2 & 3 & 4 & 5 & 6 & 7 & 8 \\
\hline 10 & 5.440 & 4.620 & 0.840 & 7.300 & 0.840 & 0.840 & 19.88 \\
\hline 11 & 4.690 & 2.330 & 0.510 & 2.310 & 8.030 & 17.390 & 35.26 \\
\hline 12 & 5.417 & 1.700 & 4.467 & 1.417 & 0.425 & 0.000 & 13.426 \\
\hline Sum & 41.577 & 52.778 & 12.097 & 33.139 & 27.767 & 37.096 & 203.83 \\
\hline $\begin{array}{c}\text { Mean } \\
\text { value }\end{array}$ & 3.465 & 4.398 & 1.008 & 2.762 & 2.314 & 3.091 & 16.986 \\
\hline
\end{tabular}

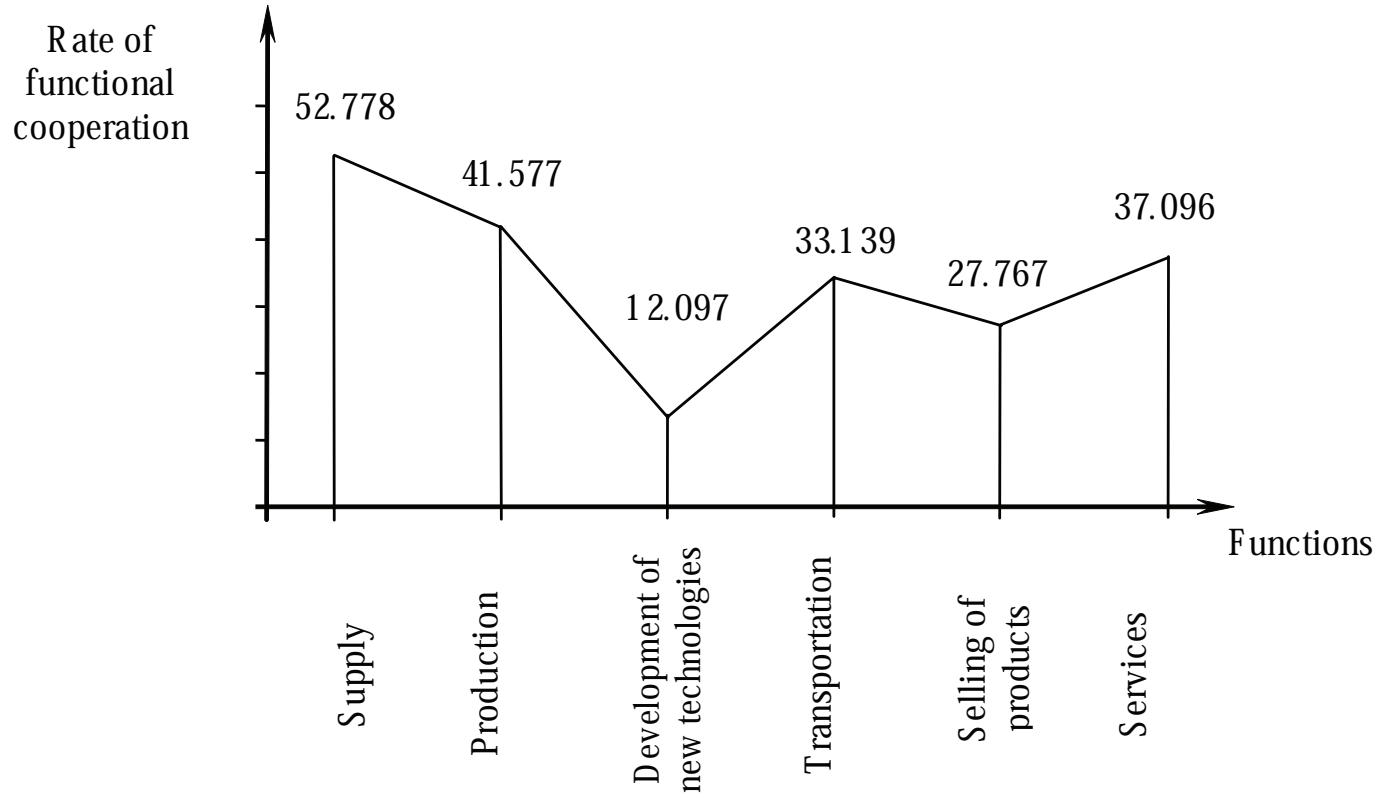

Fig. 4. The level of production functions' cooperation of the considered enterprises

\section{The influence of enterprises' cooperation on their commercial activities}

To determine the influence of general and functional cooperation on the commercial activities (and the dependence of the results obtained on it), the criteria describing various activities of the enterprises analysed, such as profitability of their capital, as well as total and net profitability were considered (Table 4).

Based on the data presented in Table 3 and Table 4, the relationship between total cooperation coefficient of enterprises and the results of their commercial activities was determined by using correlation - regression analysis according to models $1-3$. The calculation results are given in Table 5. As shown in Table 5, the influence of the total cooperation coefficient on capital profitability of an enterprise is insignificant. Its relationship with enterprise assets' profitability is a little stronger. 
In addition to determining the influence of cooperation on enterprise commercial activities, the influence of functional cooperation should be determined. This analysis is required to answer the following questions:

- what kind of functional cooperation has the strongest effect on enterprise commercial activities and its results?

- what should be the rate of functional cooperation?

The analysis of total cooperation coefficient and the criteria of enterprise's profitability has shown that cooperation most strongly affects the profitability of enterprise assets (Table 5). Therefore, its dependence on functional cooperation coefficients will be analysed.

The regression analysis has shown that functional cooperation in the area of production and development of new technologies and products has the strongest influence on profitability of enterprise assets. Therefore, each of the above functions was analysed separately. The results of calculations are given in Table 6.

The calculation results presented in Table 6 show that cooperation in production and development of new products and technologies can increase profitability of enterprise assets.

As shown by the calculation results given in Table 7, the number of partners (the cooperating enterprises) has a relatively strong influence on the enterprise performance, particularly, on the total profitability. However, this influence remains positive until a certain limit. When it is achieved, further increase in the number of partners leads to decrease of performance effectiveness. This may be accounted for by the fact that general management of a large number of enterprises is getting too complicated. This is also confirmed by the theoretical analysis of the dependence of enterprises' cooperation.

Table 4. Indicators of enterprise profitability in 2005-2007

\begin{tabular}{|c|c|c|c|c|c|c|c|c|c|c|c|c|}
\hline \multirow{2}{*}{ 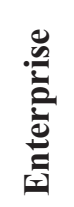 } & \multicolumn{3}{|c|}{$\begin{array}{c}\text { Capital profitability } \\
\text { (KP) }\end{array}$} & \multicolumn{3}{|c|}{$\begin{array}{c}\text { Profitability of assets } \\
\text { (TP) }\end{array}$} & \multicolumn{3}{|c|}{$\begin{array}{c}\text { Total profitability } \\
\text { (BP) }\end{array}$} & \multicolumn{3}{|c|}{$\begin{array}{l}\text { Net profitability } \\
\text { (GP) }\end{array}$} \\
\hline & 2005 & 2006 & 2007 & 2005 & 2006 & 2007 & 2005 & 2006 & 2007 & 2005 & 2006 & 2007 \\
\hline A01 & 0.01 & 0.02 & 0.02 & 0.02 & 0.015 & 0.02 & \begin{tabular}{|l|}
0.03 \\
\end{tabular} & 0.03 & \begin{tabular}{|l|}
0.04 \\
\end{tabular} & 0.19 & 0.14 & 0.16 \\
\hline $\mathrm{A} 02$ & 0.06 & 0.04 & 0.11 & 0.04 & 0.03 & 0.08 & 0.03 & 0.08 & 0.26 & 0.06 & 0.07 & 0.11 \\
\hline A03 & 0.0002 & 0.09 & 0.02 & 0.0003 & 0.02 & 0.12 & \begin{tabular}{|l|}
0.11 \\
\end{tabular} & 0.1 & \begin{tabular}{|l|}
0.13 \\
\end{tabular} & 0.0003 & 0.02 & 0.09 \\
\hline A04 & 0.1 & 0.118 & 0.19 & 0.15 & 0.22 & 0.33 & 0.18 & 0.23 & 0.3 & 0.06 & 0.05 & 0.106 \\
\hline A05 & 0.05 & 0.003 & 0.08 & 0.01 & 0.008 & 0.13 & 0.14 & 0.17 & 0.34 & 0.03 & 0.35 & 0.18 \\
\hline A06 & 0.12 & 0.042 & 0.04 & 0.22 & 0.07 & 0.08 & 0.2 & 0.15 & \begin{tabular}{|l|}
0.11 \\
\end{tabular} & 0.05 & 0.16 & 0.065 \\
\hline A07 & 0.07 & 0.002 & 0.36 & -0.3 & -0.004 & 0.05 & 0.02 & 0.21 & 0.26 & -0.33 & -0.003 & 0.12 \\
\hline A08 & 0.11 & 0.05 & 0.09 & 0.02 & 0.053 & 0.116 & 0.13 & 0.03 & 0.16 & 0.164 & 0.11 & 0.242 \\
\hline A09 & -0.01 & 0.08 & -0.006 & -0.045 & 0.01 & -0.02 & 0.01 & 0.21 & 0.13 & -0.22 & 0.005 & -0.01 \\
\hline A10 & 0.04 & 0.02 & 0.02 & 0.01 & 0.03 & -0.17 & 0.23 & 0.25 & 0.285 & 0.02 & \begin{tabular}{|l|}
0.014 \\
\end{tabular} & 0.03 \\
\hline A11 & 0.06 & 0.07 & 0.06 & 0.048 & 0.08 & 0.12 & 0.22 & \begin{tabular}{|l|}
0.19 \\
\end{tabular} & 0.2 & 0.08 & 0.06 & 0.07 \\
\hline A12 & 0.3 & 0.33 & 0.42 & 0.09 & 0.167 & 0.26 & 0.29 & 0.22 & \begin{tabular}{|l|}
0.37 \\
\end{tabular} & 0.05 & 0.13 & 0.19 \\
\hline
\end{tabular}



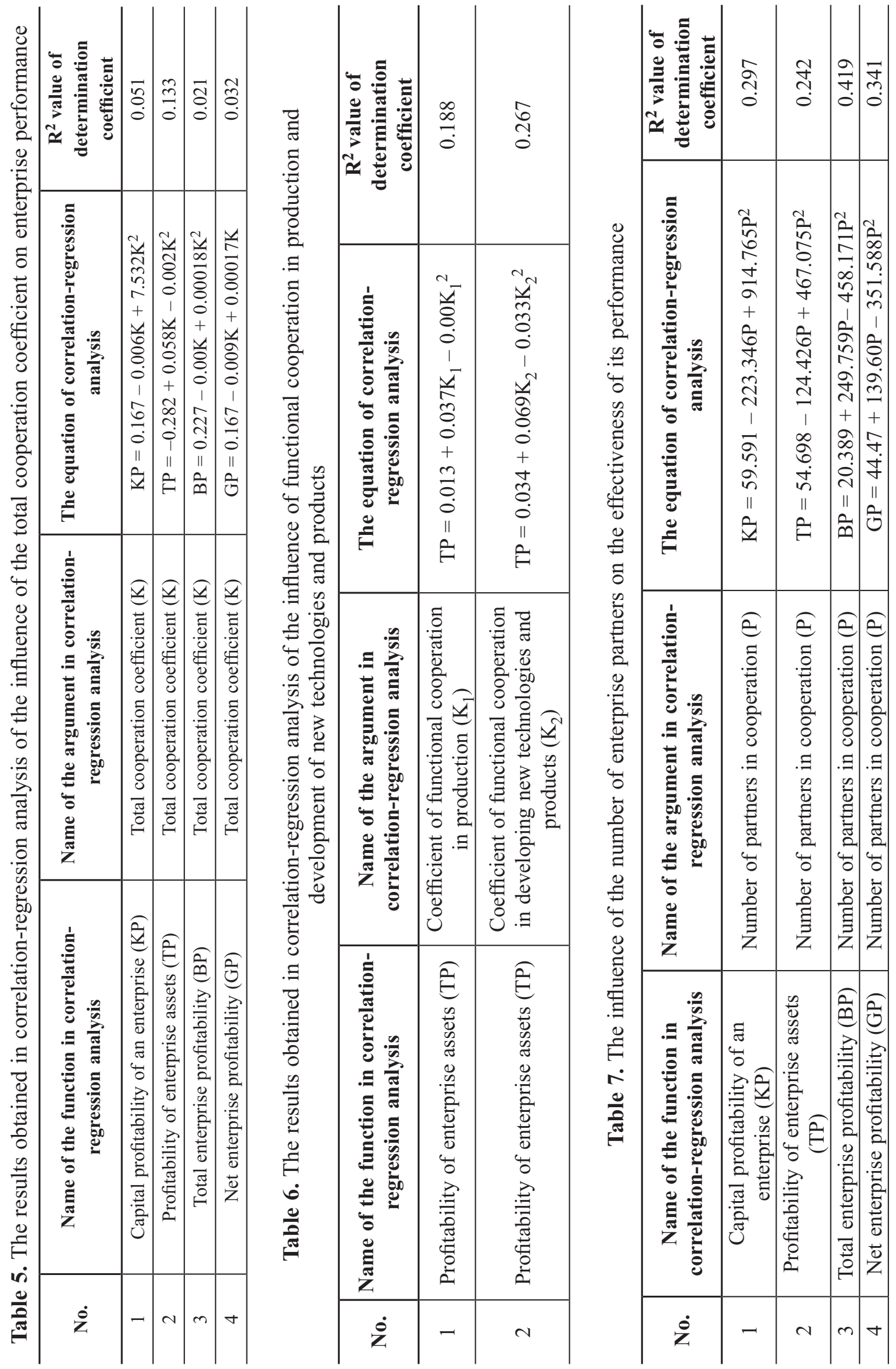


\section{Conclusions}

The calculations show that the suggested formula helps adequately describe the level of enterprise cooperation with other organisations. The analysis of cooperation influence on enterprise performance reveals that it is not strong. This means that the reasons for this, which may be associated with the organisational forms of cooperation as well as with the number of partners or the number of joint functions and the rate of functional cooperation, should be determined.

For more profound analysis of cooperation influence on the effectiveness of enterprise performance the role of cooperation in the area of production functions should be determined, and the investigation of each function in this respect should be made. The regression analysis allows us to choose the functions, having the largest effect on profitability of enterprise assets which is most sensitive to the process of enterprises' cooperation.

These functions refer to the development of production and new products and technologies. The largest effect on profitability of enterprise assets is caused by the cooperation in developing new products and technologies. However, it has been found that the cooperation level in this area is the lowest. Thus, seeking to increase profitability of an enterprise, the cooperation in this field should be increased first.

One of the main factors determining cooperation effectiveness is the number of partners (the cooperating enterprises). The correlation analysis of its influence on enterprise performance shows that it is considerable. The largest effect is produced on the total profitability of an enterprise $\left(\mathrm{R}^{2}=0,419\right)$. However, a positive effect lasts only for a limited time. Then, enterprise performance is getting worse because management of a large number of cooperating enterprises is becoming too complicated.

\section{References}

Albino, V.; Carbonara, N.; Giannoccaro, I. 2007. Supply chain cooperation in inductrial districts: a simulation analysis, European Journal of Operational Research 177: 261-280.

doi:10.1016/j.ejor.2005.12.007

Auškalnyte, R.; Ginevičius, R. 2001. The evaluation of competitive advantage by taking strategic decisions, Inzinerine Ekonomika - Engineering Economics (2): 66-71.

Axelrod, R. 1984. The evolution of cooperation. Basic Books.

Barzdenytè, B. 2000. Pricing and competition. Vilnius: Vilniaus universiteto leidykla.

Blau, P. 1964. Exchange and power in social life. New York: Willey.

Beamish, P. W. 1988. Multinational joint ventures in developing countries. London-New York.

Benisch, W. 1991. Kooperative Formen der Unternehmenszusammenfarsung. TGO. Leipzig.

Bleicher, K. 1992. Unternehmenspolitische und unternehmenskulturelle Voraussetzungen erfolgreicher strategischer Partnerschaften. Stuttgart.

Blohm, H. 1980. Kooperation, in Grochla, E. (Hrsg): HWO, Stuttgart, 1112-1117.

Brandenburger, A. M. 1997. Co-opetition: a revolution mindset that combines competition and cooperation; the game theory strategy that's changing the game of business. New York.

Brenner, T. 2005. Innovation and cooperation during the emergence of local industrial clusters: an empiri- 
cal study in Germany, European Planning Studies 13(6): 921-938. doi:10.1080/09654310500188522 Edquist, C. 1997. Systems of innovation approaches - their emergence and characteristics, in C. Edquist. Systems of Innovation: Technologies, Institutions and Organizations. London: Pinter/Cassell, 1-35.

Ginevičius, R. 2009. Quantitative evaluation of unrelated diversification of enterprise activities, Journal of Civil Engineering and Management 15(1): 105-111. doi:10.3846/1392-3730.2009.15.105-111

Ginevičius, R. 2005. Some problems of measuring absolute market concentration in modern business: priorities of development. Vilnius: Technika, 12-36 (in Lithuanian).

Ginevičius, R. 2000. Strategies of adapting enterprises to the environment, Verslas: teorija ir praktika [Business: Theory and Practice] 1(1): 10-17.

Ginevičius, R. 1998. Diversification of enterprise activities. Vilnius: Technika.

Ginevičius, R.; Andruškevičius, A. 2000. Production concentration under the market economy, Economics 51: 20-29.

Ginevičius, R.; Čirba, S. 2009. Additive measurement of market concentration, Journal of Business Economics and Management 10(3): 191-198. doi:10.3846/1611-1699.2009.10.191-198

Ginevičius, R.; Čirba, S. 2007. Determining market concentration, Journal of Business Economics and Management 8(1): 3-10.

Gounaris, S. P. 2005. Trust and commitment influences on customer retention: insights from businessto-business services, Journal of Business Research 58(2): 126-140.

doi:10.1016/S0148-2963(03)00122-X

Granovetter, M. 1985. Economic action and social structure: the problem of embeddedness, The American Journal of Sociology 91(3): 481-510. doi:10.1086/228311

Gulati, R.; Garguilo, M. 1999. Where do interorganizational networks come from? The American Journal of Sociology 104 (5): 1439-1493. doi:10.1086/210179

Gundlach, G. T. 1995. Price Predation: Legal Limits and Antitrust Considerations, Journal of Public Policy \& Marketing 14(2): 278-90.

Kaul, I. 1999. Global public goods: international cooperation in the 21st century. Oxford University Press.

Lawson, R.; Guthrie, J.; Cameron, A.; Fischer, W. Chr. 2008. Creating value through cooperation: an investigation of farmers' markets in New Zealand, British Food Journal 110(1): 11-25. doi:10.1108/00070700810844768

Levinthal, D. A.; March, J. G. 1993. The myopia of learning, Strategic Management Journal 14(S2): 95-112. doi:10.1002/smj.4250141009

Morgan, R. M., Hunt, S. O. 1999. Theory of relationship marketing, Journal of Marketing 58(3): 20-38. doi:10.2307/1252308

Novickas, J.; Savanevičienè, A. 2000. Cooperation forms of the enterprises, Inzinerine Ekonomika Engineering Economics (3): 32-38.

Porter, M. E. 1980. Competitive Advantage. New York: The Free Press.

Royer, S.; Simons, R. 2009. Evolution of cooperation and dynamics ofexpectations - implications for strategic alliances, International Journal of Strategic Business Alliances 1(1): 73-88.

doi:10.1504/IJSBA.2009.023652

Rumelt, R. P. 1991. How Much Does Industry Matter? Strategic Management Journal 12(3): 167-185. doi: $10.1002 / \mathrm{smj} .4250120302$

Sakalas, A.; Savanavičienè, A. 2000. Cooperation of enterprises and principles of workers' competence development, Inzinerine Ekonomika - Engineering Economics (5): 34-39.

Savanevičienè, A. 2001. The model of cooperation management at the enterprise level, Inzinerine Ekonomika - Engineering Economics (2): 46-52. 
Shan, M.; Walker, G.; Kogut, B. 1994. Interfirm cooperation and startup innovation in the biotechnology industry, Strategic Management Journal 15(5): 387-394. doi:10.1002/smj.4250150505

Stark, H.-U.; Helbing, D.; Schönhof, M.; Hołyst, J. A. 2008. Alternating cooperation strategies in a Route Choice Game: theory, experiments, and effects of a learning scenario, in Innocenti, A.; Sbriglia, P. (Eds.). Games, Rationality and Behaviour. Houndmills and New York: Palgrave McMillan, 256-273.

Sutcliffe, K. M.; Zaheer, A. 1998. Uncertainty in the transaction environment: An empirical test, Strategic Management Journal 19(1): 1-23.

doi:10.1002/(SICI)1097-0266(199801)19:1<1::AID-SMJ938>3.0.CO;2-5

Teece, D. J.; Pisano, G.; Shuen, A. 1997. Dynamic capabilities and strategic management, Strategic Management Journal 18(7): 509-533.

doi:10.1002/(SICI)1097-0266(199708)18:7<509::AID-SMJ882>3.0.CO;2-Z

Uzzi, B. 1997. Social structure and competition in interfirm networks: The paradox of embeddedness, Administrative Science Quarterly 42: 35-67. doi:10.2307/2393808

Wetzels, M. G. M. 1998. Service quality in customer-employee relationships: an empirical study in the after-sales services context. DATAWISE, Maastricht.

Williamson, O. E. 1981. The modern cooperation: origins, evolution, attributes, Journal of Economic Literature 19: 1537-1568.

Zajac, E. J. 1990. CEO selection, succession, compensation and firm performance: A theoretical integration and empirical analysis, Strategic Management Journal 11(3): 217-230.

doi:10.1002/smj.4250110304

\section{GAMYBOS İMONIŲ KOOPERACIJOS EFEKTYVUMAS}

\section{R. Ginevičius}

\section{Santrauka}

Kooperacija yra vienas iš įmonès strateginės elgsenos būdų siekiant išlikti rinkoje. Tai nuolatinių ilgalaikių gamybinių ryšių nustatymas tarp ūkiškai ir teisiškai savarankiškų i̇monių. Svarbus vaidmuo kooperacijoje tenka jos pasiekto lygio matavimui, nes be to neimanoma nagrinėti jos poveikio įmoniu komercinès veiklos efektyvumui, nustatyti šio poveikio ribu, efektyvios kooperacijos sąlygų ir pan. Remiantis pasiūlyta įmonių kooperacijos pasiekto lygio nustatymo formule, atlikta kooperacijos poveikio ¿monès konkurencinès veiklos rezultatams analizè parodé, kad jis nèra stiprus, vadinasi, dar nerastos tinkamos organizacinès jos formos. Kooperacija daro didžiausią itaką imonès turto pelningumui. Gamybos funkcijų kooperavimo analizè parodè, kad labiausiai imonių turto pelningumą veikia gamybos bei naujų technologijų ir produkto išvystymo kooperavimas. Didelę itaką kooperacijos efektyvumui taip pat turi partnerių skaičius.

Reikšminiai žodžiai: i̇monès kooperacija, kooperacijos matavimas, kooperacijos poveikis i̇monės komercinès veiklos rezultatams.

Romualdas GINEVIČIUS. Professor, Dr, Head of the Department of Enterprise Economics and Management, construction engineer and economist. The author of more than 350 research papers and over 20 scientific books; editor-in-chief of the 'Journal of Business Economics and Management' (located in ISI database 'Web of Science') and the journal 'Business: Theory and Practice'. Research interests: organization theory, complex quantitative evaluation of social processes and phenomena. 